症 例

縦隔リンパ節転移を伴った $\mathrm{ACTH}$ 産生肺定型カルチノイドの 1 例

坪井 光弘, 広瀬 敏幸, 住友 弘幸, 山田＼cjkstart亮

\begin{abstract}
要旨
症例は 66 歳, 女性. 全身の浮腫拉よび㑫怠感で動けなくなっているところを発見され当院に救急搬送された. ACTH およ びコルチゾールの上昇を認め, 他の内分泌学的検查と併せて ACTH 依存性クッシング症候群と診断された. 胸部 CT 検査で 左肺下葉に $1.3 \mathrm{~cm}$ の結節を認め, ACTH 産生腫瘍の疑いで手術を試行した. 術中迅速病理診断はカルチノイドであり, 左肺 下葉切除, 縦隔リンパ節郭清を行った，術後病理診断は定型カルチノイドで, 傍食道領域リンパ節に転移を伴っていた。免 疫染色では ACTH が陽性であり, ACTH 産生肺定型カルチノイド, pT1bN2M0 stage IIIA と診断された。また，術後は $\mathrm{ACTH}$ 高值の遷延がみられたが画像検査でその原因となる所見はなく, 副腎皮質ステロイド合成阻害薬の投与が開始され た. 切除 8 カ後に ACTH は正常範囲まで低下した.
\end{abstract}

索引用語：ACTH 産生腫瘍, 肺定型カルチノイド, リンパ節転移, クッシング症候群

ACTH-releasing tumor, pulmonary typical carcinoid, lymph node metastasis, Cushing's syndrome

はじめに

肺カルチノイドは原発性肺悪性腫瘍の 1〜2\%を占め る腫瘍であり ${ }^{1)}$ ，稀に副腎皮質刺激ホルモン（ACTH）を 産生し臨床的にC ushing 徵候を呈することがある。今 回, 縦隔リンパ節転移を伴った $\mathrm{ACTH}$ 産生肺定型カル チノイドの 1 手術例を経験したので文献的考察を加え報 告する.

\section{症例}

症 例: 66 歳, 女性.

主 訴：全身僚㤐感, 体動困難.

既往歴 : 高血圧, 2 型糖尿病, 高尿酸血症, 狭心症, 心 房細動, 慢性心不全, 左乳癌 (非浸潤性乳管癌で 3 年前 に手術)。

喫煙歴：なし.

現病歴 : 2 力月前から両下肢の浮腫が出現し, 食事摂 取量が減少していた，近医を受診し低カリウム血症と診

徳島県立中央病院外科

原稿受付 2021年 3 月 6 日

原稿採択 2021年 7 月 21 日
断され, L-アスパラギン酸カリウムを処方されていた.し かしその後も症状は増悪し, 自宅で動けなくなっている ところを発見され，当院に救急搬送された．

入院時現症：身長 $157 \mathrm{~cm}$, 体重 $61.7 \mathrm{~kg}$. BMI 25.0. 血 圧 133/103 mmHg. 脈拍数 $80 \mathrm{bpm}$, Af. 中心性肥満あり. 左大腿外側に裖瘡あり。

胸部単純 $\mathrm{X}$ 線 (受診時)：左中下肺野の透過性低下, 左 肋横隔膜角の鈍化を認める (Fig. 1).

血液検查 : 白血球 $7600 / \mu \mathrm{l}$, 好中球 $90.1 \%$, 血小板 6.7 万/ $\mu \mathrm{l}, \mathrm{Na} 146.7 \mathrm{mEq} / \mathrm{l}, \mathrm{K} 1.69 \mathrm{mEq} /$, 随時血糖 $309 \mathrm{mg}$ / dl, HbAlc $12.5 \%$.

内分泌学的検查 : ACTH $355.0 \mathrm{pg} / \mathrm{ml}$, コルチゾール $93.0 \mu \mathrm{g} / \mathrm{dl}$ と高值を示した. コルチゾールの日内変動は 消失しており，少量デキサメサゾン抑制試験ではコルチ ゾールの抑制を認めなかった。 CRH 負荷試験では ACTH 值は無反応であった.

頭部 MRI：下垂体に腺腫を疑う所見なし.

以上より ACTH 依存性 Cushing 症候群と診断され, 下垂体病変がなかったことから異所性 $\mathrm{ACTH}$ 産生腫瘍 が疑われた。ソマトスタチン受容体シンチグラフィ (SRS) では腫瘍性病変を示唆する異常集積を指摘できな かったが，全身 CT で左肺下葉に結節が認められた。 
胸部 CT : 左肺下葉 $\mathrm{S} 9$ に $0.9 \times 1.3 \times 1.2 \mathrm{~cm}$ の辺縁平滑 な充実性腫瘤を認めた (Fig. 2a, b)。肺門，縦隔のリンパ 節腫大は認めなかった。

PET/CT : 左肺下葉の結節を含め, 異常集積を伴う病 変は認めなかった（Fig. 3).

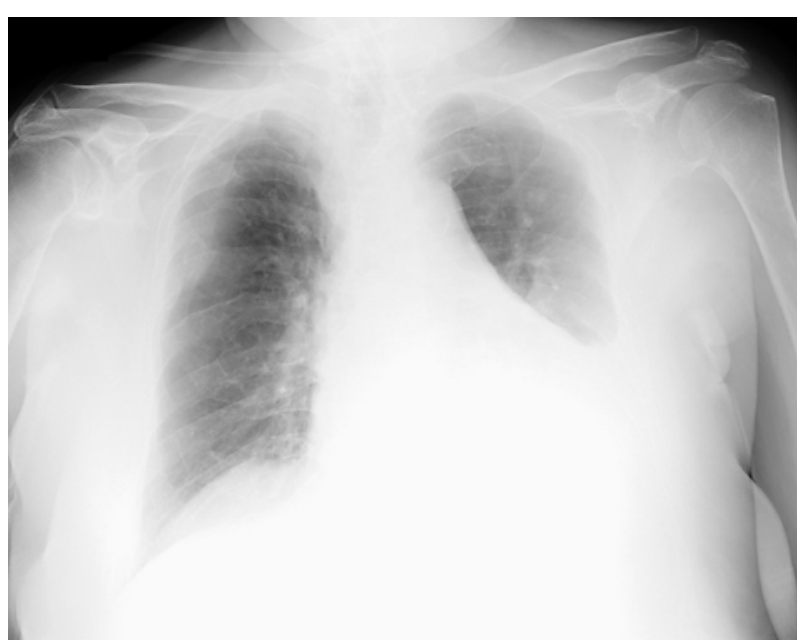

Fig. 1 Chest radiograph showed decreased radiolucency of the left middle and lower lung fields and blunting of the costophrenic angle on the left side.
気管支鏡検査：内腔に特記すべき異常所見は認めな かった。

腫瘍マーカー：CEA, CYFRA, Pro-GRP はいずれも正 常範囲内であった。

腹部を含めた全身精查でも左肺下葉結節の他に異所性

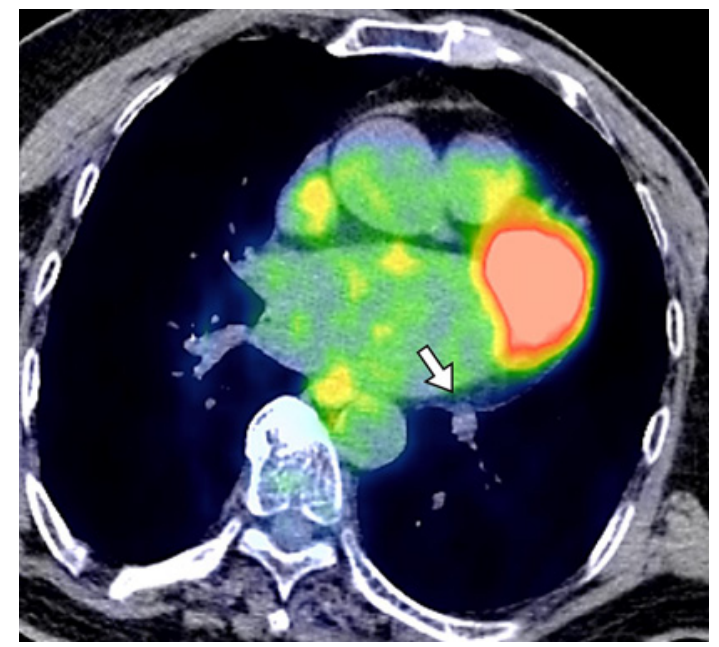

Fig. 3 Positron emission tomography-computed tomography showed no uptake in the tumor of the left lower lung (arrow).

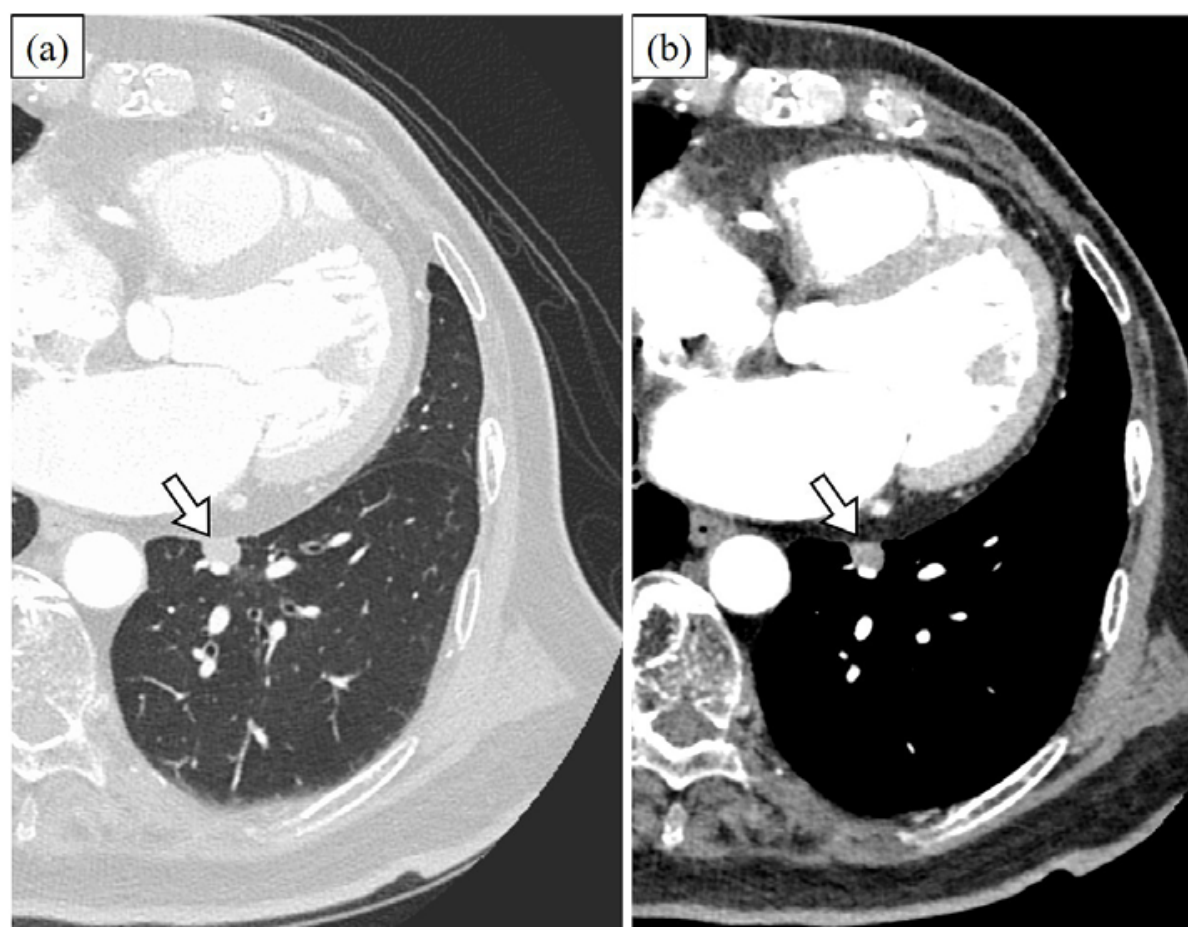

Fig. 2 Chest computed tomography showed a well-circumscribed nodule in the left lower lobe (arrow): (a) lung window, (b) mediastinal window. 


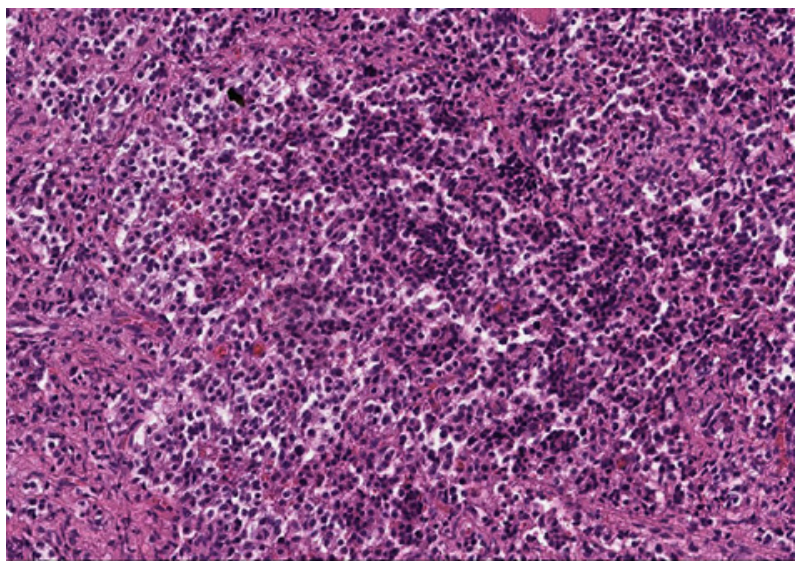

Fig. 4 Pathological findings of the resected tumor. Tumor cells with round nuclei were growing in clusters. There were no mitotic figures or necrotic areas (hematoxylin-eosin staining; magnification $\times 20$ ).

$\mathrm{ACTH}$ 産生腫瘍を疑う病変を認めなかったため, 異所性 $\mathrm{ACTH}$ 産生肺カルチノイド cT1bN0M0 stage IA2 の疑 いで外科的切除の方針とした．周術期はインスリンスラ イディングスケール法による血糖管理を行った。

手術所見：3 ポート胸腔鏡下に手術を行った。まず病 変を含めて肺部分切除を行った．術中迅速病理診断はカ ルチノイドであり, 左肺下葉切除, リンパ節郭清を行っ た．術中に播種やリンパ節転移を疑う所見は認めなかっ た．術前 $\mathrm{CT}$ で気管分岐部にリンパ節を認めなかったこ と, 術前の糖尿病のコントロールが不良であり周術期耐 糖能異常による創傷治癒遅延が予想されること, 術後の ステロイド投与などの理由から気管支断端の血流温存を 優先する方針とし, 下縦隔郭清は食道傍リンパ節, 肺勒 帯リンパ節に留め, 気管分岐部の郭清は省略した。手術 時間 143 分, 出血 $33 \mathrm{~g}$.

病理組織学的所見：摘出標本は $1.1 \mathrm{~cm}$ で割面黄白色 調の辺縁平滑な充実性腫瘍であった，腫瘍は類円形の核 を有する異型細胞が小胞巣状に増殖しており, 核分裂像 や壊死像は認めなかった (Fig. 4). Ki-67 は $2 \%$ 以下で あった. 免疫染色では Chromogranin A, Synaptophysin, TTF-1，ACTH に陽性であった（Fig. 5)。食道傍リンパ 節領域に 1 個のリンパ節転移を認めた. 以上から $\mathrm{ACTH}$ 産生肺定型カルチノイド pT1bN2M0 stage IIIA と診断 された。

術後経過：経口ハイドロコルチゾンにて補充療法を行 い, 術後 5 日目に退院した. しかし, 術後 5 カ月の時点 でも ACTH 高值（197 pg/ml）が遷延し, 副腎皮質ステ
ロイド合成酵素阻害薬であるメチラポンの投与を継続し た. 病変の遺残や再発, 他の原因病変を念頭に画像検査 を行ったが, 異所性 ACTH 産生腫瘍を疑う病変や, 胸腔 内のリンパ節腫大は認めなかった，その後もメチラポン の投与を継続し経過観察を継続したところ, 術後 8 力月 に $\mathrm{ACTH}$ の低下を認めた。さらに $\mathrm{ACTH}$ およびコルチ ゾールの日内変動, 少量デキサメサゾン抑制試験による コルチゾールの正常範囲までの抑制が確認されたため, 異所性 ACTH 症候群は寛解したと考えられた.

\section{考察}

異所性 ACTH 産生腫瘍である肺定型カルチノイドに 対して手術を行い, 術後に縦隔リンパ節転移が明らかに なった症例を経験した。ささらに，本症例では術後に血中 ACTH 高值が遷延した特異な経過を示した.

異所性 ACTH 産生腫瘍は 1969 年に Liddle らによっ てはじめて報告された . 本疾患では下垂体外より分泌さ れた ACTHにより副腎皮質機能立進を来たして Cushing 徵候, 代謝異常などの特徵的な症状を呈する. 異所性 $\mathrm{ACTH}$ 産生腫瘍の頻度は気管支肺カルチノイドが $22.7 \%$ と最多で, 次いで肺小細胞癌が $21.7 \%$ と肺病変が 多く, 胸腔内病変が $48.9 \%$ を占めている ${ }^{3}$. 異所性 $\mathrm{ACTH}$ 産生気管支肺カルチノイドは一般的に 0.5 2 cm の小結 節であると報告されているため ${ }^{4)}$, 病巣の発見にしばしば 難渋し, さらには発見できたとしても, 組織を採取し病 理学的診断をつけることはさらに困難であると考えられ る. そこで病変の検索や質的診断の補助の目的に, 神経 内分泌腫瘍に特徴的なソマトスタチン受容体に結合する 標識, オクトレオチドを用いた SRS が行われている. SRS ではカルチノイド, 肺小細胞癌が高い感度 (>75\%) で検出可能とされている一方で, 肉芽腫, 炎症性疾患で も陽性となり特異的ではない。 そのため, 欧米のガイド ラインはSRSをCT や MRI とどの画像検査に追加して 行うことを推奨している ${ }^{5,6)}$. 自験例で指摘された結節は $\mathrm{CT}$ 画像上 $1.3 \mathrm{~cm}$ と小さな病変であり, シンチグラフィ でも集積を認めず，術前の診断が困難であったため，術 中迅速診断でカルチノイドと判明した後に肺葉切除を 行った．神経内分泌腫瘍に対する新たな診断モダリティ として，オクトレオチドをDOTA な゙のキレート剤を 介してポジトロン核種であるガリウム 68 で標識した, ${ }^{68} \mathrm{Ga}-\mathrm{DOTATOC}$ などによる SR-PET/CT が近年注目さ れており，高い診断精度が報告されている ${ }^{7.8)}$. 標識の精 

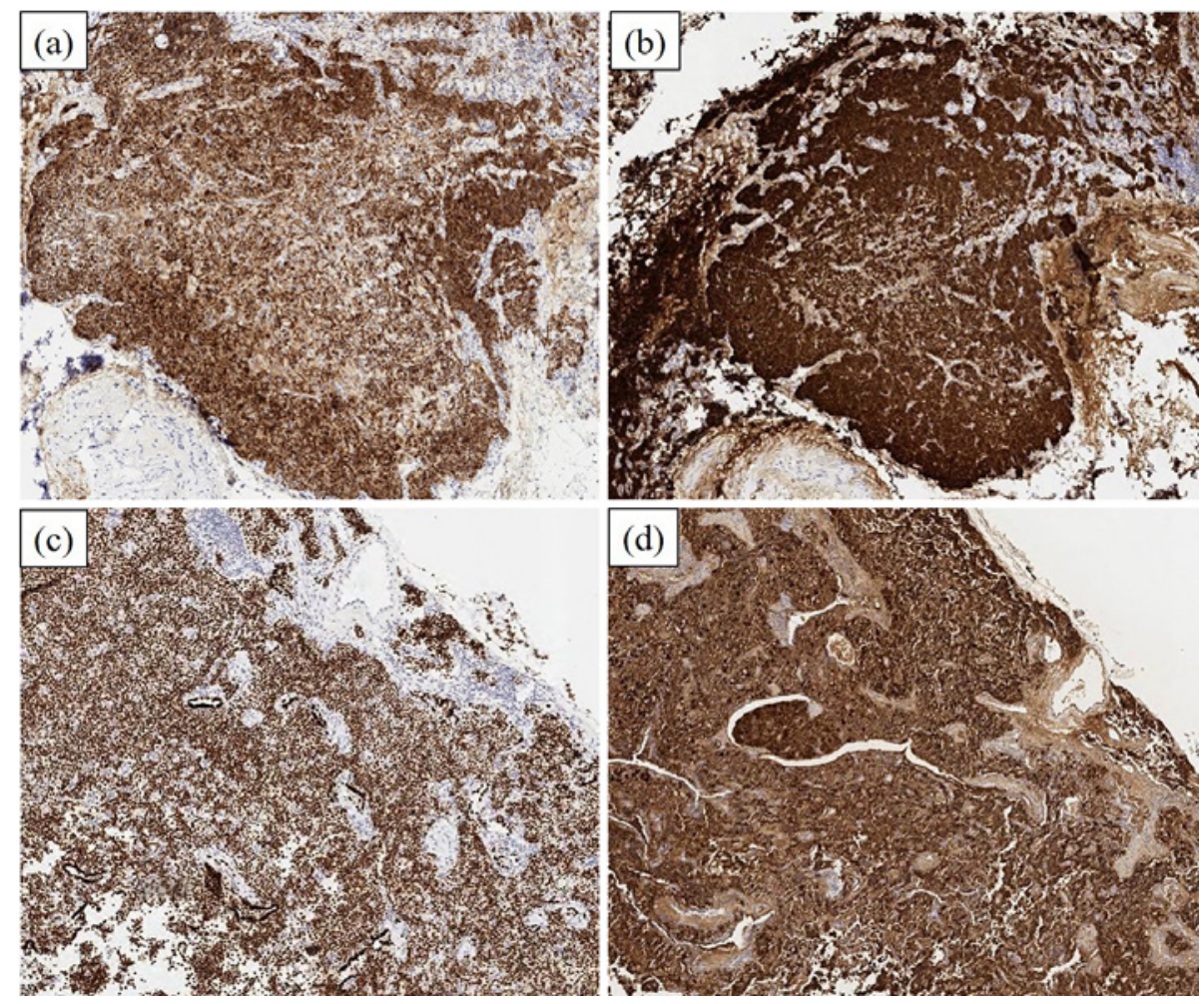

Fig. 5 Immunohistochemical findings. Positive findings of immunohistochemical staining for chromogranin A (a), Synaptophysin (b), TTF-1 (c), and ACTH (d).

製技術や機器, 検査費用の問題はあるものの, 今後の普 及により診断精度の向上が期待できる.

自験例では食道傍リンパ節領域に 1 個のリンパ節転移 を認めた，定型的カルチノイドのリンパ節転移陽性率は 8〜 15\% ${ }^{9)}$, 再発率は 3〜 5\% ${ }^{10)}$ と報告されている. すなわ ち, 定型カルチノイドは低悪性度で予後良好とされてい るが, その一方で Cushing 症候群を呈する肺カルチノイ ドは定型であっても悪性度が高いとする報告もある。 Boddaertらは 59 例の Cushing 症候群を呈した肺カル チノイドを検討し, 定型カルチノイド 49 例, 異型カルチ ノイド 8 例という割合であったにも関わらず， 24 例 (47\%)にリンパ節転移を認め, $20 \%$ に再発を認めたと報 告している ${ }^{11}$. 自験例では合併症予防の観点から気管分 岐部の郭清を省略したが, この結果からは Cushing 症候 群を呈する肺カルチノイドに対してはできるだけ標準手 術, 系統的リンパ節郭清を行うことが望ましいと考えら れる，ただし, 術後補助化学療法については確立された エビデンスはない. Detterbeckはリンパ節転移陽性症例 の術後補助化学療法を推奨しているがその根拠は示され ていない(10). 反対に, 非定型カルチノイドにおいては術後
補助化学療法の有効性を否定する報告が近年なされてい る ${ }^{12,13)}$. 進行・再発カルチノイドに対する全身化学療法と しては, これまでにシスプラチン/エトポシド, スニチニ ブ，エベロリムスなどの有効性が報告されている，また， オクトレオチドシンチグラフィ陽性症例やカルチノイド 症候群を呈する症例では, オクトレオチド併用レジメン が有効であったとの報告がある ${ }^{14-16}$.

自験例では術後，ACTHの高值が遷延した．異所性 ACTH 産生腫瘍では外科治療により Cushing 症候群が 改善することが知られており，これまでの報告の多くで は術後, 速やかな ACTH の低下が得られている. 検索し 得た中では川野ら ${ }^{17)}$, 園川ら ${ }^{18}$ が, 異所性 ACTH 産生肺 カルチノイドの術後に ACTH の高值が遷延したと報告 しており, 園川らの症例では, 縦隔リンパ節転移を伴う 肺カルチノイド切除後に ACTH は一過性に低下したが その後再上昇し Cushing 症候群の再燃を認めたため, 副 腎皮質ステロイド合成阻害剂であるトリロスタンが投与 され, 約 1 年後に病状改善により投薬を終了していた. 術後の画像検査では原因病変は指摘されていない. 園川 らの報告と同様に, 自験例でも術後 $\mathrm{ACTH}$ の高值が遷 
延したため副腎皮質ステロイド合成阻害剤の投与を行 い, 8 力月後に病状の改善を得た. ACTH 産生腫瘍切除 後にホルモン高值が遷延する原因は不明であり，また本 来 ACTH の低下には寄与しない副腎皮質ステロイド合 成阻害剤の投与が病状の改善と関与するのかどうかも明 らかではないが, 画像検査で原因を疑う病変の存在が否 定的であるときは, 時間を要してもホルモンの低下が得 られる可能性があると考えられた。

\section{結語}

異所性 ACTH 産生肺定型カルチノイドに対して手術 を行った症例を報告した. Cushing 徴候を伴った肺カル チノイドは縦隔リンパ節転移の頻度が高く, 手術術式の 選択には注意が必要であると考えられた。

\section{利益相反}

本論文において開示すべき利益相反は無い.

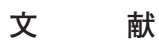

1. Bertino EM, Confer PD, Colonna JE, Ross P, Otterson GA. Pulmonary neuroendocrine/carcinoid tumors: a review article. Cancer 2009; 115: 4434-41.

2. Liddle GW, Nicholson WE, Island DP, Orth DN, Abe K, Lowder SC. Clinical and laboratory studies of ectopic humoral syndromes. Recent Prog Horm Res 1969; 25: 283314 .

3. Ejaz S, Vassilopoulou-Sellin R, Busaidy NL, Hu MI, Waguespack SG, Jimenez C, et al. Cushing Syndrome Secondary to Ectopic Adrenocorticotropic Hormone Secretion: The University of Texas MD Anderson Cancer Center Experience. Cancer 2011; 117: 4381-9.

4. Sahdev A, Reznek RH, Evanson J, Grossman AB. Imaging in Cushing's syndrome. Arq Bras Endocrinol Metabol 2007; 51: 1319-28.

5. Kwekkeboom DJ, Krenning EP, Scheidhauer K, Lewington V, Lebtahi R, Grossman A, et al. Mallorca Consensus Conference participants; European Neuroendocrine Tumor Society. ENETS Consensus Guidelines for the Standards of Care in Neuroendocrine Tumors: somatostatin receptor imaging with (111) In-pentetreotide. Neuroendocrinology 2009; 90: 184-9.

6. Ramage JK, Ahmed A, Ardill J, Bax N, Breen DJ, Caplin
ME, et al. UK and Ireland Neuroendocrine Tumour Society. Guidelines for the management of gastroenteropancreatic neuroendocrine (including carcinoid) tumours (NETs). Gut 2012; 61: 6-32.

7. 窪田和雄. 神経内分泌腫瘍の PET - SPECT. 内分泌甲状 腺外会誌 2015; 32: 112-5.

8. Treglia G, Castaldi P, Rindi G, Giordano A, Rufini V. Diagnostic performance of Gallium-68 somatostatin receptor PET and PET/CT in patients with thoracic and gastroenteropancreatic neuroendocrine tumours: a metaanalysis. Endocrine 2012; 42: 80-7.

9. Ginsberg RJ. Carcinoid tumors. In: Shields TW, LoCicero J III, Ponn RE, editors. General Thoracic Surgery. 5th ed. Philadelphia: Lippincott Williams \& Wilkins; 2000: 1493502.

10. Detterbeck FC. Management of carcinoid tumors. Ann Thorac Surg 2010; 89: 998-1005.

11. Boddaert G, Grand B, Le Pimpec-Barthes F, Cazes A, Bertagna X, Riquet M. Bronchial carcinoid tumors causing Cushing's syndrome: more aggressive behavior and the need for early diagnosis. Ann Thorac Surg 2012; 94: 1823-9.

12. Anderson KL Jr, Mulvihill MS, Speicher PJ, Yerokun BA, Gulack BC, Nussbaum DP, et al. Adjuvant chemotherapy does not confer superior survival in patients with atypical carcinoid tumors. Ann Thorac Surg 2017; 104: $1221-30$.

13. Wegner RE, Abel S, Hasan S, Horne ZD, Colonias A, Weksler B, et al. The role of adjuvant therapy for atypical bronchopulmonary carcinoids. Lung Cancer 2019; 131: $90-4$.

14. Chong CR, Wirth LJ, Nishino M, Chen AB, Sholl LM, Kulke MH, et al. Chemotherapy for locally advanced and metastatic pulmonary carcinoid tumors. Lung Cancer 2014; 86: 241-6.

15. Kulke MH, Lenz HJ, Meropol NJ, Posey J, Ryan DP, Picus J, et al. Activity of sunitinib in patients with advanced neuroendocrine tumors. J Clin Oncol 2008; 26: 3403-10.

16. Yao JC, Phan AT, Chang DZ, Wolff RA, Hess K, Gupta S, et al. Efficacy of RAD001 (everolimus) and octreotide LAR in advanced low- to intermediate-grade neuroendo- 
crine tumors: results of a phase II study. J Clin Oncol 2008; 26: 4311-8.

17. 川野 裕, 山口 豊, 門山周文, 粐木 茂, 馬場雅行, 佐 藤展将, 他. 血中 ACTH 高值を示した肺カルチノイドの
一切除例. 肺癌 1984; 24: 439-44.

18. 園川卓海, 竹ヶ原京志郎, 井上達哉, 榎本 豊, 寺崎泰弘, 臼田実男. Cushing 症候群を伴った ACTH 産生肺定型力 ルチノイドの 1 切除例. 肺癌 2020; 60: 358-63.

\title{
A case of ACTH-releasing pulmonary typical carcinoid with lymph node metastasis
}

\author{
Mitsuhiro Tsuboi, Toshiyuki Hirose, Hiroyuki Sumitomo, Ryo Yamada
}

Department of Surgery, Tokushima Prefectural Hospital, Tokushima, Japan

The patient was a 66-year-old female who was found lying immobile in her house and brought to our hospital in an ambulance. Blood tests showed elevated serum adrenocorticotropic hormone (ACTH) and cortisol levels, indicating ACTH-related Cushing's syndrome. Chest computed tomography revealed a 1.3-cm nodule in the inferior lobe of the left lung. The patient underwent surgery for a suspected ACTH-releasing lung tumor. The frozen section diagnosis was a pulmonary carcinoid tumor, and left lower lobectomy with lymph node dissection was performed. The pathological diagnosis was a typical carcinoid with paraesophageal lymph node metastasis. Immunohistochemical staining for ACTH was positive, and she was diagnosed with ACTH-producing pulmonary typical carcinoid, pT1bN2M0, stage IIIA. After surgery, the serum ACTH remained elevated, although postoperative imaging examination did not show any other tumors. After the administration of metyrapone, the serum ACTH and cortisol levels improved to their normal ranges 8 months after resection. 